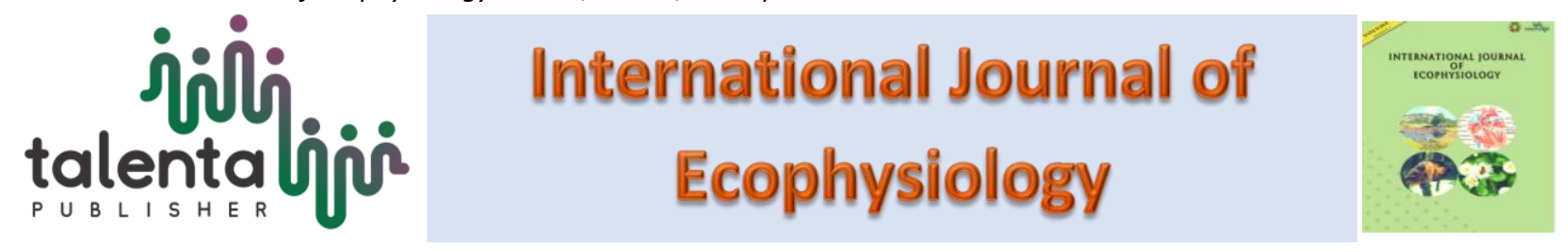

\title{
Degradation Level and Wetland Rice Rehabilitation Effort in Medan Krio Village Sunggal District Deli Serdang
}

\author{
Mhd Zakaria Sbln ${ }^{1}$, Abdul Rauf ${ }^{1}$, Sarifuddin ${ }^{1}$ \\ ${ }^{1}$ Program Pascasarjana Agroteknologi, Fakultas Pertanian, Universitas sumatera Utara, Jalan Prof. A. \\ Sofyan No.3 Kampus USU Padang Bulan, Medan 20115
}

\begin{abstract}
The purposes of this research are to know the level of paddy field degradation, mapping level of paddy field degradation and analyze effort of paddy field rehabilitation in Beringin Subdistrict of Deli Serdang Regency of North Sumatera Indonesia to increase rice productivity. This research was conducted in Medan Krio Village, District Sunggal Regency Deli Serdang of North Sumatera. The study was conducted in March to July 2017. This research used nonfactorial Randomized Block Design (RBD) with 5 levels organic dosage treatment of Compost Waste City, i.e: B0: Control, B1: Dose 1.5\% (36,00 ton/ha), B2: Dose 3\% (72,00 ton/ha), B3: Dose 4.5\% (108,00 ton/ha), B4: Dose 6\% (144,0 ton/ha). The parameters that will be analyzed are the physical, chemical and biological properties of soil in paddy fields. The result showed, treatment with Dose 6\% (B4) can (1) improve physical properties of soil Bulk Density, Porosity and the effective depth of soil; (2) increase the C-organic content, N-Total levels of P-Available, CEC soil, and low C/N Ratio; (3) increase Soil organic matter and total Microbes. So, Treatment Dose 6\% (B4) of compost waste city gives the best effect to the physical, chemical and biological properties of soil in paddy fields.
\end{abstract}

Keyword: Level of Degradation, Dose of Organic Material, Production of Rice Plant Received 6 November 2019| Revised 27 December2019| Accepted 29 January2020

\section{Introduction}

In degraded paddy fields, one of which is indicated by organic matter and low potassium. Organic matter has an important role in determining the ability of the soil to support plants so that if soil organic matter levels decrease, the ability of the soil to support crop productivity also decreases [1]. According to the Agency for Agricultural Research and Development [2], organic materials are very beneficial for increasing agricultural production both in quality and quantity, reducing environmental pollution, and improving the quality of land in a sustainable manner.

The role of organic matter is very important in increasing soil fertility and will determine soil productivity. The role of organic matter not only plays a role in the supply of plant nutrients but

\footnotetext{
*Corresponding author at: 1Program Pascasarjana Agroteknologi, Fakultas Pertanian, Universitas sumatera Utara, Jalan Prof. A. Sofyan No.3 Kampus USU Padang Bulan, Medan 20115, Indonesia

E-mail address: Mhdzakaria25@gmail.com
} 
is far more important for the improvement of physical, biological and the other chemical properties of soils such as the $\mathrm{pH}$ of the soil, the capacity of the exchange of cations and soil anions, soil buffering capacity and neutralization of toxic elements such as $\mathrm{Fe}, \mathrm{Al}, \mathrm{Mn}$ and other heavy metals [3].

In addition to rice straw compost, there is also municipal waste compost. According to Sandrawati et al., [4] municipal waste compost can be made from municipal waste in the form of market waste and household waste that has been weathered (composting). It is expected that with the proper use of compost, i.e municipal waste compost, the physical properties of the soil can be improved, namely the structure and texture of the soil through the formation of more stable aggregates, loose and good aeration and soil drainage.

\section{Materials and Methods}

This research was conducted from March 2017 to July 2017in Medan Krio Village, Sunggal District, Deli Serdang Regency. Soil analysis was carried out at the Soil and Water Conservation and Physics Laboratory and the Technology Research Laboratory of the Faculty of Agriculture, University of North Sumatra.

The study uses a non factorial randomized block design with a dose of organic matter (B) City Waste Compost, consisting of 5 (five) levels, namely: $\mathrm{B} 0=$ Control, $\mathrm{B} 1=1.5 \%$ (36.00 tons / ha), B2 $=3 \%$ (72.00 tons $/$ ha), B3 $=4.5 \%$ (108.00 tons $/$ ha), B4 $=6 \%$ (144.0 tons $/$ ha). The data were analyzed using variance based on the linear model as follows: $Y i j=\mu+\rho i+t j+\varepsilon i j$ Where: $Y i j=$ Response of observed plants, $\mu=$ Common median value, $\rho i=$ The effect of the $i$ th block, $\mathrm{t} j=$ Treatment effect on the $\mathrm{j}$-test, $\varepsilon \mathrm{ij}=$ Error effect of the $\mathrm{j}$-treatment and the $\mathrm{i}$-block. If the results of the ANOVA show a significant effect, then analysis proceed to the DMRT test at the level of 5\% [5]. The parameters measured physical properties: Bulk Density (g / cm3), Porosity (\%). Chemical properties; Soil pH, C-Oragnik N- Total (\%), C/N, P-Available (ppm), K2O (mg / 100), CEC (Me / 100), KB (\%), biological properties: Organic Material (\%), Total Microbes (CFU).

\section{Result and Discussion}

\subsection{Effect of organic matterin municipal solid waste to soil physical properties}

The effect of organic matter composting of municipal waste on lowland rice cultivation on soil physical properties can be seen from the observation parameters which include soil physical properties, bulk density $(\mathrm{g} / \mathrm{cm} 3)$, and porosity $(\%)$ of soil. The results showed that the provision of organic matter compost of city waste significantly affected the physical properties of the soil. The results are presented in Table 1. The highest Bulk Density is found in the B0 (Control) while the lowest in the treatment B4 (6\%). The best effect was B4 (6\%) but the density was not significantly different from the B3 $(4.5 \%)$. This is due to the top surface layer which is rich in 
organic matter and has a loose bulk density lower than the solid bottom layer with low humus content. The denser a soil, the higher its bulk density, which means that it is more difficult for water to penetrate the roots of plants [6].

Grainy surface soil, is due to the relatively high organic matter content. The granules cause low ground leaching density and high total pore. The highest porosity was in the B4 treatment (6\%) while the lowest was in the B0 (Control) treatment. The highest porosity was in the B4 treatment $(6 \%)$ while the lowest was in the B0 (Control) treatment. The effect of the provision of organic matter compost municipal waste to the best porosity B4 (6\%) but not significantly different from the B3 treatment (4.5\%). The greater the total porosity value of the soil also shows the maximum storage capacity of the water by the soil the greater. The ability of the soil to pass water and air does not always correlate closely with its total pore value but is more influenced by the percentage of pore size distribution. If the distribution of the pore size of soil is dominated by large pores (macropores), in general, the soil has the ability to store moisture is low, but this soil has the ability to pass water and air that is large. Porous soil means that sufficient soil has pore space for water movement and fading in and out of the soil freely, otherwise if the soil is not porous [7].

Table 1 Soil physical properties Bulk density (g/cm3), Porosity (\%), due to the provision of municipal organic waste compost.

\begin{tabular}{ccc}
\hline \multirow{2}{*}{ Treatment } & \multicolumn{2}{c}{ Soil Physical Properties } \\
\cline { 2 - 3 } & $\mathrm{BD}\left(\mathrm{g} / \mathrm{cm}^{3}\right)$ & Prositas $(\%)$ \\
\hline B0 (Control) & $1.13 \mathrm{a}$ & $546.60 \mathrm{c}$ \\
$\mathrm{B} 1(1.5 \% \mathrm{BO})$ & $1.05 \mathrm{~b}$ & $57.26 \mathrm{~b}$ \\
$\mathrm{~B} 2(3 \% \mathrm{BO})$ & $1.05 \mathrm{~b}$ & $57.86 \mathrm{ab}$ \\
$\mathrm{B} 3(4.5 \% \mathrm{BO})$ & $1.03 \mathrm{~b}$ & $58.24 \mathrm{ab}$ \\
$\mathrm{B} 4(6 \% \mathrm{BO})$ & $1.03 \mathrm{~b}$ & $58.78 \mathrm{ab}$ \\
\hline
\end{tabular}

Note: Numbers followed by the same letter in the same column indicatewhich is not significant based on the Ducan multiple range test at $5 \%$

3.2 The effect of organic matter in municipal solid waste to the soil chemical properties

The effect of the organic matter giving municipal compost organic matter on lowland rice planting on soil chemical properties can be seen from parameters including soil $\mathrm{pH}, \mathrm{C}$-organic, N-Total, C/N, P-Available, and soil CEC. The results of the analysis of variance on the chemical nature of the data indicate that the provision of organic compost waste has a significant effect on the chemical properties of the soil.

The average difference test results in Table 2 on the soil chemical properties can be seen from the observation parameters which include Soil pH, C-organic, N-Total, C/N, P-Available, and Soil CEC using Duncan's multiple range test, presented in Table 2 . The average difference test results in Table 2 for the chemical properties of soil $\mathrm{pH}$ Soil, C-organic, N-Total, C/N, PAvailable, and Soil CEC using Duncan's multiple range test, are presented in Table 2. The 
highest soil $\mathrm{pH}$ is found in $\mathrm{B} 4$ treatment $(6 \%)$ while the lowest was B1 treatment (1.5\%). The best effect of organic matter compost on municipal waste on soil $\mathrm{pH}$ is the treatment of $\mathrm{B} 4(6 \%)$ but not significantly different from B2 (3\%).

The addition of immature organic matter will cause the slow process of soil improvement where organic waste that has not been decomposed properly will still release organic acids. The highest C-Organic was found in the B4 treatment (6\%) while the lowest was in the B0 (Control) treatment. The best effect of organic waste composting on C-Organic is compost B4 (6\%) but not significantly different from B3 (4.5\%). The more organic fertilizer added to the soil, the greater the increase in organic $\mathrm{C}$-content in the soil. Explaining that the provision of organic material can increase soil C-organic content and also by increasing C-organic soil can also affect the nature of the soil to be better physically, chemically and biologically.

Tabel 2 Soil chemical properties of Soil pH, C-organic, N-Total, C/N, P-Available, and Soil CEC due to the provision of organic matter compost municipal waste

\begin{tabular}{lcccccc}
\hline & \multicolumn{5}{c}{ Soil Chemical Properties } \\
\cline { 2 - 7 } Treatment & Soil pH & $\mathrm{C}$ & $\mathrm{N}$ & $\mathrm{C} / \mathrm{N}$ & $\mathrm{P}$ & $\mathrm{CEC}$ \\
\hline & & $(\%)$ & $(\%)$ & & $(\mathrm{ppm})$ & $(\mathrm{me} / 100 \mathrm{~g})$ \\
$\mathrm{B} 0($ Control $)$ & $6.26 \mathrm{bc}$ & $0.68 \mathrm{c}$ & $0.16 \mathrm{~d}$ & $4.45 \mathrm{bc}$ & $12.39 \mathrm{c}$ & $17.69 \mathrm{c}$ \\
$\mathrm{B} 1(1.5 \% \mathrm{BO})$ & $6.23 \mathrm{c}$ & $0.82 \mathrm{c}$ & $0.27 \mathrm{c}$ & $3.36 \mathrm{c}$ & $16.80 \mathrm{~b}$ & $18.27 \mathrm{bc}$ \\
$\mathrm{B} 2(3 \% \mathrm{BO})$ & $6.31 \mathrm{ab}$ & $1.50 \mathrm{~b}$ & $0.32 \mathrm{c}$ & $4.80 \mathrm{ab}$ & $17.15 \mathrm{~b}$ & $18.52 \mathrm{bc}$ \\
$\mathrm{B} 3(4.5 \% \mathrm{BO})$ & $6.29 \mathrm{bc}$ & $2.39 \mathrm{a}$ & $0.40 \mathrm{~b}$ & $5.97 \mathrm{a}$ & $17.60 \mathrm{~b}$ & $19.12 \mathrm{~b}$ \\
$\mathrm{~B} 4(6 \% \mathrm{BO})$ & $6.48 \mathrm{a}$ & $2.44 \mathrm{a}$ & $0.47 \mathrm{a}$ & $5.26 \mathrm{ab}$ & $20.36 \mathrm{a}$ & $22.62 \mathrm{a}$ \\
\hline
\end{tabular}

Note: Numbers followed by the same letter in the same column indicatewhich is not significant based on the Ducan multiple range test at $5 \%$

The highest N-Total was in the B4 treatment $(6 \%)$ while the lowest was in the B0 (Control) treatment. The best effect of municipal organic waste compost on N-Total is B4 (6\%). This increase in $\mathrm{N}$-total soil is derived from the mineralization of organic matter supplied. Afandi [8] explains that the process of $\mathrm{N}$ loss in the soil can be caused by being absorbed by plants, used by microorganisms, $\mathrm{N}$ is still in the form of $\mathrm{NH} 4$ + bound by clay minerals so that it cannot be used by plants, $\mathrm{N}$ is also still in the form of NO3- which is easily washed away by rainwater, and land conditions that are still flooded with rush drainage and in unfavorable soil aeration also occur denitrification and also volatilization in the form of NH3 (ammonia).

The highest soil $\mathrm{C} / \mathrm{N}$ was found in the $\mathrm{B} 3$ treatment $(4.5 \%)$ while the lowest was in the B1 treatment $(1.5 \%)$. The best effect of organic waste composting on $\mathrm{C} / \mathrm{N}$ was B3 (4.5\%) treatment, but it was not significantly different from B4 (6\%). The provision of organic material that is mature enough at the time of planting or a week after planting can provide the right conditions [9]. 
The high $\mathrm{C} / \mathrm{N}$ ratio will make decomposition difficult, while the lace $\mathrm{C} / \mathrm{N}$ ratio shows a greater percentage than material that is easily decomposed. The highest P-Available was in the B4 treatment (6\%) while the lowest was in the B0 (Control) treatment. The best effect of municipal organic waste compost on P-Available is B4 (6\%). This is due to organic acids produced from the decomposition process of organic material that can chelate $\mathrm{Fe}$ and $\mathrm{Al}$ so that $\mathrm{P}$ will be available to plants, organic acids in forming a chelate with $\mathrm{Al}$ and $\mathrm{Fe}$ which results in the release of phosphate in soil solution. Organic matter in addition to improving physical fertility can also increase the available $\mathrm{P}$ of the soil because it can form complex bonds with dissolved $\mathrm{Al}$, thereby reducing the retention of $\mathrm{P}$ by $\mathrm{Al}$ and $\mathrm{Fe}$. The highest $\mathrm{CEC}$ was in the $\mathrm{B} 4$ treatment $(6 \%)$ while the lowest was in the B0 (Control) treatment. The best effect of municipal organic compost waste on CEC on Soil is B4 treatment (6\%). The provision of organic matter, even though small, affected the soil CEC, so the higher the soil organic matter the higher the CEC soil [10].

Soil organic matter indirectly plays a role in increasing aggregate stability, water holding capacity, CEC, soil buffering capacity and decreasing P sorption by soil. The higher the organic matter in the soil, the higher the CEC, where this provision applies if the other factors are the same. Furthermore, it is said that the size of the CEC is influenced by the nature and characteristics of the soil which include the reaction of the soil or $\mathrm{pH}$ where with increasing soil $\mathrm{pH}$ the CEC will also increase [11].

\subsection{Effect of organic matter in municipal solid waste on soil biological characteristics}

The effect of organic material in municipal solid waste on lowland rice planting on soil biological characteristics includes organic material and total microbial. The results indicate that the provision of organic compost waste has a significant effect on the soil's biological characteristics (Table 3).

Table 3 Soil biological characteristics of organic material and total soil microbes due to the provision of organic matter compost municipal waste

\begin{tabular}{lcc}
\hline \multirow{2}{*}{ Treatment } & \multicolumn{2}{c}{ Soil Biological Properties } \\
\cline { 2 - 3 } & Organic Matter $(\%)$ & Total Microbe $(\mathrm{CFU} / \mathrm{ml})$ \\
\hline B0 (Control) & $1.17 \mathrm{c}$ & $4.46 \times 10^{7} \mathrm{c}$ \\
$\mathrm{B} 1(1.5 \% \mathrm{BO})$ & $1.57 \mathrm{c}$ & $5.75 \times 10^{7} \mathrm{ab}$ \\
$\mathrm{B} 2(3 \% \mathrm{BO})$ & $2.59 \mathrm{~b}$ & $5.45 \times 10^{7} \mathrm{~b}$ \\
$\mathrm{~B} 3(4.5 \% \mathrm{BO})$ & $4.12 \mathrm{a}$ & $5.90 \times 10^{7} \mathrm{ab}$ \\
$\mathrm{B} 4(6 \% \mathrm{BO})$ & $4.20 \mathrm{a}$ & $6.18 \times 10^{7} \mathrm{a}$ \\
\hline
\end{tabular}

Note: Figures followed by the same letter in the same column indicate that it is not significant based on the Ducan multiple range test at the level of $5 \%$.

The highest Soil Organic Material was found in the B4 treatment (6\%) while the lowest was in the B0 (Control) treatment. The best effect of organic matter composting 
municipal waste on Organic Material is B4 (6\%) treatment but not significantly different from B3 (4.5\%). The application of organic material significantly affected total porosity, an increase in total pore space after application of organic fertilizer. That is because compost and manure undergo a process of decomposition and gradually produce humus. The interaction of topsoil with soil particles will create a more stable soil structure and increase pore space [12].

The best effect of organic municipal waste compost on the total microbial treatment was B4 (6\%) but not significantly different from B1 (1.5\%) and B3 (4.5\%). This increase in microbes occurs because of its role as a remodel which will ultimately increase the important nutrients for plants in this due to the increase in C-organic content that can also be caused by the number of microorganisms that decompose the organic material is relatively large. According to Cardoso et al., [13], the population of soil microorganisms increases with the addition of organic matter into the soil in terms of the circulation of $\mathrm{CO} 2$. The amount and activity of soil microbes is influenced by soil type, plant growth (species composition, soil cover, root penetration to the soil, litter, etc.), the treatment given to the soil, planting, macro and microclimate from each location. A rhizosphere area is an important place because the ecological conditions in the area are influenced by root exudates. The number of soil microbes and metabolic activity is higher in the rhizosphere than in the surrounding area [7].

\section{Conclusion}

The effect of giving organic matter compost of city garbage has a significant effect on the physical properties of soil, Bulk on the chemical properties of soil $\mathrm{pH}, \mathrm{C}$-organic, N-Total, C/N, P-Available, CEC soil and Biology of Soil Organic Material and Total Microbial. To increase rice productivity in Medan Krio Village, Sunggal District, Deli Serdang Regency, it is recommended that 72 tons / ha of organic fertilizer be given up to $3 \%$ organic matter content.

\section{REFERENCES}

[1] Guntur, P. O., Hardy, G., dan Razali. Pemetaan Status C-Organik Tanah Sawah Di Desa Sei Bamban, Kecamatan Sei Bamban Kabupaten Serdang Bedagai. Jurnal Agroekoteknologi Vol. 4 (1) :1830 - 1837. 2015.

[2] [Badan Litbang] Badan Penelitian dan Pengembangan Pertanian. 2006. PupukOrganik dan Pupuk Hayati.Departemen Pertanian. Jakarta.

[3] Atmojo, S. W. Peranan Bahan Organik Terhadap Kesuburan Tanah Dan Upaya Pengelolaannya. Pidato Pengukuhan Guru Besar Ilmu Kesuburan Tanah. Sebelas Maret University Press. Surakarta. 2003.

[4] Sandrawati, A, E.T. Sofyan, O. Mulyani. Pengaruh Kompos Sampah Kota dan Pupuk Kandang Sapi Terhadap Sifat Kimia Tanah dan Hasil Tanaman Jagung Manis (Zea mays saccharata) pada Fluventic Eutrudepts Asal Jatinagor Kabupaten Sumedang. Laporan Penelitian Dasar (LITSAR). Universitas Padjadjaran. 2007.

[5] Sastrosupadi, A., Rancangan Percobaan Praktis Bidang Pertanian. Penerbit Kanisus. Yogyakarta. 2000. 
[6] Syamsuddin. Fisika Tanah. Buku Ajar Universitas Hasanuddin, Makassar. 2012.

[7] Hanafiah, K. A., 2005. Dasar-Dasar Ilmu Tanah. Raja Grafindo Persada, Jakarta.

[8] Afandi FN, Bambang Siswanto, Yulia Nuraini. Pengaruh Pemberian Berbagai Jenis Bahan Organik Terhadap Sifat Kimia Tanah Pada Pertumbuhan Dan Produksi Tanaman Ubi Jalar Di Entisol Ngrangkah Pawon, Kediri. Jurnal Tanah dan Sumberdaya Lahan Vol 2 No $2: 237-244,2015$.

[9] Bachtiar R.A., M. Rifki, Y. R. Nurhayat, S. Wulandari, R. A. Kutsiadi, A. Hanifa, M. Cahyadi. Komposisi Unsur Hara Kompos yang Dibuat dengan Bantuan Agen Dekomposer Limbah Bioetanol pada Level yang Berbeda. Sains Peternakan Vol. 16 (2), 63-68. 2018.

[10] Truong THH and Petra Marschner. Addition of residues with different $\mathrm{C} / \mathrm{N}$ ratio in soil over time individually or as mixes - effect on nutrient availability and microbial biomass depends on amendment rate and frequency. J. Soil Sci. Plant Nutr. vol. 18 no.4 Temuco dic. 2018

[11] Fageria. NK. Role of Soil Organic Matter in Maintaining Sustainability of Cropping Systems. Journal of . Volume 43, Issue 16. 2012.

[12] Zulkarnain, M. Pengaruh Kompos, Pupuk Kandang dan Custom-Bio terhadap Sifat Tanah, Pertumbuhan dan Hasil Tebu Pada Entisol di Kebun Ngrangkah-Pawon, Kediri. Universitas Brawijaya Malang. 2013.

[13] Cardoso EJBN, RLF Vasconcellos; D Bini; MYH Miyauchi; CA dos Santos; PRL Alves; AM de Paula; AS Nakatani; JM Pereira; MANogueira. Soil health: looking for suitable indicators. What should be considered to assess the effects of use and management on soil health?. Sci. agric. (Piracicaba, Braz.) vol.70 no.4 Piracicaba July/Aug. 2013. 